\title{
PENGARUH KUALITAS PELAYANAN DAN PERSEPSI HARGA TERHADAP KEPUASAN DAN LOYALITAS PELANGGAN GOJEK DI KOTA DENPASAR
}

\section{Dewa Gede Adi Adnyana ${ }^{1}$ Ni Wayan Sri Suprapti²}

\author{
${ }^{1,2}$ Fakultas Ekonomi dan Bisnis Universitas Udayana, Bali, Indonesia \\ e-mail: dewaadnyana13@gmail.com
}

\begin{abstract}
ABSTRAK
Penelitian ini bertujuan untuk mengetahui pengaruh kualitas pelayanan dan persepsi harga terhadap kepuasan dan loyalitas pelanggan Gojek di Kota Denpasar. Metode pengempulan data yang digunakan adalah survey dan kuesioner sebagai alat pengumpulan data. Jumlah sampel dalam penelitian ini sebanyak 120 responden pengguna jasa transportasi Gojek dengan menggunakan teknik pengambilan sampel purposive sampling. Penelitian ini menggunakan teknik analisis jalur (path analysis) dengan bantuan program SPSS. Hasil penelitian menunjukkan bahwa seluruh hipotesis diterima yaitu 1) kualitas pelayanan berpengaruh positif dan signifikan terhadap kepuasan, 2) persepsi harga berpengaruh positif dan signifikan terhadap kepuasan, 3) kualitas berpengaruh positif dan signifikan terhadap loyalitas pelanggan, 4) persepsi harga berpengaruh positif dan signifikan terhadap loyalitas pelanggan. 5) kepuasan berpengaruh positif dan signifikan terhadap loyalitas pelanggan.
\end{abstract}

Kata Kunci: kualitas pelayanan, persepsi harga, kepuasan, loyalitas pelanggan.

\begin{abstract}
The aim of this research is to know the effect of service quality and price perceptions on customer satisfaction and loyalty on Gojek passengers in Denpasar. Data collecting method used survey questionnaire as a data collection tool. The number of samples in this study were 120 respondents of transportation service users of Gojek by using purposive sampling technique. This research use path analysis technique with the help of SPSS program. The result of the research shows that all hypotheses are accepted, 1) service quality had positive and significant effect on satisfaction, 2) price perceptions had positive and significant effect on satisfactions, 3) service quality had positive and significant effect on customer loyalty, 4) price perceptions had positive and significant effect on customer loyalty, 5) satisfaction had positive and significant effect on customer loyalty.
\end{abstract}

Keywords: service quality, price perceptions, satisfaction, customer loyalty. 


\section{PENDAHULUAN}

Indonesia merupakan negara berkembang dengan pertumbuhan penduduk yang tinggi. Beberapa provinsi di Indonesia terus mengalami peningkatan jumlah penduduk setiap tahunnya, seperti Jakarta dengan laju pertumbuhan penduduk sebesar 1.09\%, Jawa Barat 1.56\%, Yogyakarta 1.19\%, Banten 2.27\%, dan Bali dengan laju pertumbuhan sebesar 1.23\%(www.bps.go.id). Peningkatan pertumbuhan penduduk yang tinggi tentu dapat menimbulkan beberapa masalah sehingga harus dibarengi dengan peningkatan pelayanan umum disegala bidang sesuai dengan kebutuhan masyarakat sekarang ini, termasuk kebutuhan akan transportasi.

Pemasalahan yang sering muncul di daerah yang memiliki jumlah penduduk yang padat seperti Bali, khususnya Kota Denpasar adalah masalah kemacetan. Aktifitas masyarakat yang tinggal di Denpasar relatif lebih tinggi dibandingkan wilayah lain di Bali. Hal ini dikarenakan Denpasar merupakan ibukota provinsi sehingga Kota Denpasar menjadi pusat pendidikan, pusat perdagangan, dan pemerintahan. Penduduk Kota Denpasar memiliki tingkat mobilitas yang tinggi dan untuk mengatasi masalah tersebut masyarakat membutuhkan transportasi yang cepat, aman, dan nyaman.

Jasa transportasi telah mengalami perkembangan yang sangat pesat, saat ini transportasi umum sudah dapat diakses melalui internet. Perkembangan ini memudahkan masyarakat dalam memanfaatkan pelayanan jasa transportasi umum. Masyarakat kini dapat menggunakan jasa transportasi umum dimana dan kapan pun 
mereka inginkan. Kini masyarakat yang tinggal di Daerah Perkotaan sudah mulai beralih menggunakan jasa transportasi umum.

Jasa transportasi online adalah industri yang populer sekarang ini. Keberadaan transportasi online membuat orang yang ingin memesan dan menggunakan jasa transportasi umum seperti ojek dan taksi tidak perlu lagi pergi ke pangkalan ojek atau terminal, cukup hanya melalui aplikasi di smartphone. Cara pemesanan ini sangat disukai karena lebih mudah dan praktis. Saat ini ada banyak pilihan jasa transportasi online di Indonesia seperti Gojek, Grab, dan Uber.

Gojek adalah sebuah penyedia jasa layanan berbasis online. Gojek menjadi salah satu solusi mengatasi masalah kemacetan di daerah perkotaan. Aplikasi Gojek sangat mudah digunakan baik oleh para pelajar, pekerja, dan masyarakat luas lainnya. Gojek memiliki produk jasa seperti Go-Ride yang merupakan jasa angkutan menggunakan sepeda motor, Go-Car merupakan jasa angkutan yang menggunakan mobil, dan terdapat juga produk jasa lainnya yaitu: Go-Food, GoSend, Go-Mart, Go-Med, Go-Shop, Go-Box, Go-Clean, Go-Tix, Go-Pulsa.

Persaingan pada industri jasa transportasi online mengharuskan perusahaan berlomba-lomba untuk memberikan kualitas pelayanan yang terbaik untuk menjaga kepuasan dari pelanggan (Farida dkk., 2016). Apabila pelanggan sudah merasa puas maka selanjutnya tinggal mendapatkan dan mempertahankan loyalitas pelanggan, kepuasan pelanggan sangat tergantung penilaian pelanggan terhadap kualitas dari produk atau jasa yang ditawarkan (Yesenia \& Siregar, 2014). Kualitas pelayanan yang diberikan jasa transportasi online masih dikeluhkan oleh pelanggan seperti 
dari segi aplikasi dan pengemudi ojek yang kadang tidak mematuhi standarisasi pelayanan yang telah ditetapkan perusahaan.

Berdasarkan hasil pra survei yang dilakukan terhadap 30 responden maka dapat dijelaskan bahwa ada beberapa faktor yang mempengaruhi pelanggan kurang loyal dalam menggunakan jasa transportasi Gojek. Pra survei dilakukan kepada responden yang merupakan pengguna Gojek. Berikut ini adalah hasil pra survei yang dilakukan.

Berdasarkan hasil survei pendahuluan sebagian besar responden menganggap bahwa loyalitas pelanggan terhadap Gojek dipengaruhi kualitas pelayanan dan persepsi harga. Ada lima faktor untuk menentukan tingkat kepuasan konsumen yaitu: kualitas produk, kualitas pelayanan, harga, faktor emosi dan kemudahan (Irawan, 2002: 37). Hal tersebut juga diperkuat pendapat oleh Zeithaml dan Bitner (2003: 81) yang menjelaskan bahwa kepuasan pelanggan dipengaruhi oleh kualitas produk, kualitas pelayanan atau jasa, emosi, haga dan biaya.

Kualitas pelayanan adalah faktor yang menentukan keberhasilan dimana kemampuan perusahaan dalam memberikan kualitas pelayanan yang berkualitas kepada konsumen dan sebagai strategi perusahaan untuk mempertahaan diri dan mencapai kesuksesan dalam menghadapi persaingan Lupiyoadi (2013:181). Dengan memberikan kualitas pelayanan yang baik maka perusahaan juga akan menadapatkan respon yang baik juga dari pelanggan. Penelitian sebelumnya yang dilakukan Aryani dan Rosinta (2010) menyatakan kualitas pelayanan mempunyai pengaruh positif dan signifikan terhadap kepuasan pelanggan. 
Harga adalah sejumlah uang yang dibutuhkan untuk mendapatkan suatu barang atau jasa (Stanton, 2007: 22). Harga adalah variabel penting dalam sebuah pemasaran, dimana harga dapat mempengaruhi pengambilan keputusan kosumen untuk membeli suatu barang atau jasa Tjiptono (2008: 67). Bagi pelanggan yang sensitif terhadap harga, maka akan mempersepsikan harga adalah sumber kepuasan yang penting karena mereka akan memperoleh value of money yang tinggi (Irawan, 2002: 38). Penelitian yang dilakukan Lenzun dkk. (2014) menyatakan harga berpengaruh positif dan signifikan terhadap kepuasan pelanggan.

Kepuasan merupakan elemen penting yang mencerminkan keberhasilan dari produsen ataupun penyedia jasa. Kata kepuasan (satisfaction) berasal dari bahasa Latin "satis" (artinya cukup baik, memadai) dan "facio" (melakukan atau membuat), sehingga kepuasan bisa diartikan sebagai "upaya pemenuhan sesuatu" atau "membuat sesuatu memadai" (Tjiptono, 2012:292).

Menurut Kotler dan Amstrong (2012:222), kepuasan (satisfaction) adalah perasaan senang atau kecewa seseorang yang timbul karena membandingkan kinerja yang telah dipersepsikan produk (atau hasil) terhadap ekspektasi mereka. Jika kinerja gagal memenuhi harapan, pelanggan akan merasa tidak puas dan sebaliknya jika kinerja sesuai dengan harapan bahkan lebih maka pelanggan akan puas dan senang. Faktor utama penentu kepuasan pelanggan adalah persepsi pelanggan terhadap kualitas jasa (Lupiyoadi, 2013:192).

Maka dapat disimpulkan kepuasan konsumen merupakan respon pelanggan setelah membandingkan antara kenyataan dengan harapan konsumen setelah pemakaian suatu produk atau jasa. Terciptanya kepuasan konsumen dapat 
memberikan manfaat, diantaranya hubungan antara perusahaandan pelanggan menjadi harmonis, memberikan dasar yang baik bagi pembelianulang dan terciptanya loyalitas konsumen, dan membentuk suatu rekomendasidari mulut kemulut (word of mouth) yang menguntungkan bagi perusahaan.

Kepuasan pelanggan adalah perasaan yang menyenangkan yang didapat saat mendapatkan sesuatu atau sesuatu yang diinginkan terjadi (Tjiptono \& Fandy, 2008: 292). Kepuasan dipengaruhi oleh persepsi pelanggan terhadap manfaat yang diterima dibandingkan dengan pengobanan yang dikeluarkan ketika membeli atau menggunakan suatu barang atau jasa. Penelitian yang dilakukan Montolalu (2013), Setiawan \& Sayuti (2017) menyatakan bahwa kepuasan berpengaruh positif dan signifikan terhadap loyalitas pelanggan.

Salah satu alasan yang menyebabkan ketidakpuasan pelangganadalah tidak terpenuhinya harapan seperti yang diinginkan. Misalkanalasan kualitas yang tidak bagus, pelayanan yang tidak memuaskan, danharga yang mahal (Tjiptono,2008:50). Maka pelanggan yang puasakan membeli dan mencoba lagi akan tetapi sebaliknya pelanggan yang merasa tidak puas, kemungkinan akan melakukan komplain dan perusahaan harus dapat menyelesaikan komplain tersebut agar pelanggan dapat merasa puas.

Loyalitas pelanggan adalah komitmen pelanggan terhadap suatu merek, berdasarkan sikap yang sangat positif dan tercermin dalam pembelian ulang yang konsisten (Tjiptono, 2012:110). Tanpa pembelian berulang maka tidak ada loyalitas. Komitmen untuk membeli kembali merupakan sikap yang paling penting untuk menciptakan loyalitas pelanggan. Ikatan emosional juga dibutuhkan untuk 
membuat pelanggan menjadi loyal dan mendorong mereka terus melakukan pembelian terhadap produk dan jasa perusahaan (Griffin, 2012:97). Menurut Kotler et al. (2009:138) loyalitas pelanggan adalah kesediaan pelanggan untuk membeli dari suatu perusahaan dalam waktu yang panjang dan merekomendasikan produk kepada teman, termasuk preferensi keinginan dan niat membeli di masa yang akan datang.

Loyalitas pelanggan merupakan manifestasi dan kelanjutan dari kepuasan pelanggan dalam menggunakan jasa pelayanan diberikan oleh perusahaan sehingga tetap menjadi konsumen dari perusahaan tersebut (Semuel dkk., 2009). Loyalitas pelanggan juga dapat didefinisikan sebagai kesetiaan pelanggan terhadap suatu produk atau jasa perusahaan dan melaukan pembelian secara konsisten dan terusmenerus. Penelitian yang dilakukan Wendha dkk. (2013) yang menyatakan semakin baik kualitas pelayanan yang diberikan perusahaan maka loyalitas pelanggan akan semakin meningkat.

Penelitian sebelumnya Rizan dkk. (2015) berpendapat harga, kualitas pelayanan, dan brand image berpengaruh positif dan signifikan terhadap kepuasan pelanggan. Hermawan el al. (2017) menyatakan kualitas pelayanan, persepsi harga, dan citra perusahaan berpengaruh positif dan signifikan terhadap loyalitas pelanggan layanan telekomunikasi. Kurniasari dan Ernawati (2012) menyatakan kepuasan pelanggan, harga, dan kepercayaan berpengaruh positif dan signifikan terhadap loyalitas pelanggan. Kitapci et al. (2014), Dominic dan Guzzo (2010), kualitas pelayanan berpengaruh positif dan signifikan terhadap kepuasan pelanggan dan niat membeli kembali. Lesander (2013) menyatakan promosi berpengaruh 
positif terhadap kepuasan pelanggan. Penelitian yang dilakukan Akbar dan Parvez (2009) padaindutri telekomunikasi menyatakan bahwa kualitas pelayanan, kepercayaan, dan kepuasan berpengaruh positif dan signifikan terhadap loyalitas pelanggan. Santoso dan Aprianingsih (2017), Jonathan (2013), dan Ahmed et al. (2010) menyatakan bahwa kualitas pelayanan dan harga berpengaruh signifikan terhadap loyalitas pelanggan dimana kepuasan sebagai varaibel pemediasi.

Kotler et al. (2009:143) menjelaskan bahwa Kualitas (quality) adalah totalitas fitur dan karakteristik produk atau jasa yang bergantung pada kemampuannya untuk memuaskan kebutuhan yang dinyatakan. Kualitas pelayanan adalah setiap tindakan atau kegiatan yang dapat ditawarkan oleh satu pihak kepada pihak lain, dan pada dasarnya jasa tidak berwujud serta tidak mengakibatkan kepemilikan apapun (Kotler dan Amstrong, 2012:152). Lupiyoadi (2013:181) menjelaskan bahwa kualitas pelayanan adalah faktor yang menentukan tingkat keberhasilan suatu perusahaan dimana kemampuan perusahaan dalam memberikan pelayanan yang berkualitas kepada konsumen dan sebagai strategi perusahaan untuk mempertahankan diri dan mencapai kesuksesan dalam menghadapi persaingan.

Tjiptono (2014:268) menjelaskan bahwa kualitas layanan berfokus pada upaya pemenuhan kebutuhan pelanggan serta ketepatan penyampaian untuk mengimbangi harapan pelanggan. Kualitas layanan dapat dievaluasi dengan cara membandingkan kualitas yang dialami atau diterima pelanggan perusahaan dengan layanan yang diharapkan. Mardikawati dan Farida (2013) menyatakan bahwa kualitas layanan adalah sifat dari penampilan produk atau kinerja yang merupakan bagian utama strategi perusahaan dalam rangka meraih keunggulan yang 
berkesinambungan, baik sebagai pemimpin pasar ataupun strategi untuk terus tumbuh.

Penelitian ini bertujuan untuk menjelaskan: (1) pengaruh kualitas pelayanan terhadap kepuasan pelanggan Gojek, (2) pengaruh persepsi harga terhadap kepuasan pelanggan Gojek, (3) pengaruh kualitas pelayanan terhadap loyalitas pelanggan Gojek, (4) pengaruh persepsi harga terhadap loyalitas pelanggan Gojek, dan (5) pengaruh kepuasan terhadap loyalitas pelanggan Gojek.

Penelitian yang dilakukan Montalu (2013) berpendapat bahwa kualitas pelayanan berpengaruh terhadap kepuasan pelanggan, ini artinya jika kualitas pelayanan pada perusahaan ditingkatkan akan berpengaruh terhadap kepuasan pelanggan. ini didukung oleh pendapat dari Mamud et al. (2013) dan Rahman et al. (2012) yang menyatakan kepuasan pelanggan berpengaruh positif dan signifikan terhadap kepuasan.

$\mathrm{H}_{1}$ : Kualitas pelayanan berpengaruh positif dan signifikan terhadap kepuasan.

Menurut Hermawan et al. (2017) menyatakan bahwa persepsi harga berpengaruh positif dan signifikan terhadap kepuasan pelanggan. diperkuat penelitian yang dilakukan Suwandi dkk. (2015), Hasanah dan Harti (2012) berpendapat bahwa harga berpengaruh positif dan signifikan terhadap kepuasan.

$\mathrm{H}_{2}$ : Persepsi harga berpengaruh positif dan signifikan terhadap kepuasan.

Menurut Akbar dan Parvez (2009) berpendapat kualiatas pelayanan adalah sesuatu yang konsisten memenuhi atau melampaui kepuasan pelanggan. Peneltian yang dilakukan Kurniasih (2012) menyatakan bahwa kualitas pelayanan berpengaruh positif dan signifikan terhadap loyalitas pelanggan bengkel Astra 
Motor Siliwangi Semarang. Ini diperkuat dari hasil penelitian yang dilakukan Wendha dkk. (2013) dan Basir et al. (2015) kualitas pelayanan berpengaruh positif dan signifikan terhadap loyalitas pelanggan.

$\mathrm{H}_{3}$ : Kualitas pelayanan berpengaruh positif dan signifikan terhadap loyalitas pelanggan.

Hasil studi Hasanah dan Harti (2012) menyatakan harga yang diberikan perusahaan dapat mempengaruhi loyalitas pelanggan. Kurniasih (2012) dan Suwandi dkk. (2015) menyatakan harga berpengaruh positif dan signifikan terhadap loyalitas pelanggan. Hal tersebut diperkuat dari penelitian sebelumnya oleh Hermawan et al. (2017) yang menyatakan persepsi harga berpengaruh positif dan signifikan terhadap loyalitas pelanggan.

$\mathrm{H}_{4}$ : Persepsi harga berpengaruh positif dan signifikan terhadap loyalitas pelanggan. Menurut Gummusoy dan Koesoglu (2016) kepuasan pelanggan dan loyalitas pelanggan memiliki hubungan yang sangat kuat. Hal ini didukung oleh penelitian yang dilakukan Khairani dan Hati (2013), Farida dkk. (2016), Boohene dan Agyapong (2011) yang menyatakan bahwa kepuasan berpengaruh positif dan signifikan terhadap loyalitas pelanggan.

$\mathrm{H}_{5:}$ Kepuasan berpengaruh positif dan signifikan terhadap loyalitas pelanggan.

\section{METODE PENELITIAN}

Penelitian ini tergolong penelitian asosiatif, yaitu penelitian yang bertujuan untuk mengetahui hubungan dua variable atau lebih. Gojek di Kota Denpasar dipilih sebagai lokasi penelitian karena Denpasar merupakan pusat pendidikan, 
perdagangan, dan pemerintahan sehingga penawaran Gojek masih terpusat di Kota Denpasar.

Populasi dalam penelitian ini adalah seluruh pengguna Gojek di Kota Denpasar. Penentuan sampel menggunakan metode non probability sampling dengan teknik purposive sampling dengan kriteria sampel yaitu pelanggan yang telah penggunakan Gojek minimal dua kali dalam seminggu. Penentuan sampel dalam penelitian ini berdasarkan acuan dari Ghozali (2011: 121), sehingga kriteria ini menghasilkan rentang $18 \times(5-10)=90-180$. Berdasarkan batasan tersebut maka penelitian ini mengambil sampel sebanyak 120 responden karena ukuran sampel tersebut sudah termasuk rentang $90-180$.

Metode pengumpulan data yang digunakan adalah survey yaitu dengan menggunakan kuesioner sebagai intsrumen penelitian. Penyebaran kuesioner menggunakan dua cara yaitu secara langsung dan online menggunakan Google form. Data yang telah terkumpul nantinya akan ditabulasi untuk dianalisis menggunakan teknik statistik deskritif dan teknik statistik inferensial. Analisis deskriptif bertujuan untuk mengetahui karakteristik dan tanggapan responden mengenai item-item pernyataan dalam kuesioner, sedangkan statistik inferensial untuk menguji kebenaran hipotesis-hipotesis yang telah dirumuskan dengan menggunakan teknik analisis jalur (path analysis).

\section{HASIL DAN PEMBAHASAN}

Karakteristik responden dapat dilihat dari variabel jenis kelamin, usia, pendidikan dan pekerjaan. Dalam penelitian ini didominasi oleh responden berjenis kelamin perempuan yaitu sebanyak 63 orang ( 52.5 persen) dan responden berjenis 
kelamin laki-laki sebanyak 57 orang (47.5 persen). Hal ini ada hubungannya dengan tidak semua perempuan dapat mengendarai sepeda motor sehingga membutuhkan akses layanan trasportasi yang memudahkan dalam beraktivitas, perempuan juga cenderung melakukan hal - hal yang praktis dan efisien sehingga menuntut perempuan untuk bergerak lebih cepat dan efektif. Berdasarkan variabel usia sebagian besar didominasi oleh reponden yang berusia 21-30 tahun yaitu sebanyak 77 orang (64,2 persen) dan responden dengan usia $>40$ tahun sebanyak 3 orang (2.5 persen) menjadi responden dengan jumlah paling sedikit. Berdasarkan variabel tingkat pendidikan, didominasi oleh responden dengan tingkat pendidikan terakhir SMA yaitu sebanyak 81 orang (67.5 persen) dan responden dengan tingkat pendidikan sarjana yaitu sebanyak 39 orang (32.5 persen) berada pada posisi kedua. Berdasarkan variabel pekerjaan, menunjukkan sebagai besar responden pada penelitian ini masih berstatus pelajar/mahasiswa yaitu sebanyak 53 orang (44.2 persen) dari total responden, sedangkan sisanya memiliki memiliki pekerjaan sebagai karyawan swasta sebanyak 36 orang (30 persen), wiraswasta sebanyak 14 orang (11.7 persen), pegawai/PNS sebanyak (3.33 persen) dan yang memiliki jenis pekerjaan lainnya seperti ibu rumah tangga, satpam, dan driver sebanyak 13 orang (10.8 persen) menjadi responden paling sedikit.

Uji validitas dilakukan untuk mengukur validitas instrumen, yaitu suatu intsrumen pengukur dikatakan valid jika intsrumen tersebut mengukur apa yang seharusnya diukur. Validitas penunjukan tingkat ketepatan antara data yang diteliti oleh peneliti dengan data yang sesungguhnya. Hasil uji validitas dari variabelvariabel yang diuji dapat dilihat pada Tabel 1 . 
Tabel 1.

Hasil Uji Validitas

\begin{tabular}{|c|c|c|c|c|}
\hline No & Variabel & Indikator & Koefisien Korelasi & Keterangan \\
\hline 1 & Kualitas Pelayanan & $\begin{array}{l}\mathrm{X}_{1.1} \\
\mathrm{X}_{1.2} \\
\mathrm{X}_{1.3} \\
\mathrm{X}_{1.4} \\
\mathrm{X}_{1.5}\end{array}$ & $\begin{array}{l}0,858 \\
0,894 \\
0,902 \\
0,845 \\
0,856\end{array}$ & $\begin{array}{l}\text { Valid } \\
\text { Valid } \\
\text { Valid } \\
\text { Valid } \\
\text { Valid }\end{array}$ \\
\hline 2 & Persepsi harga & $\begin{array}{l}\mathrm{X}_{2.1} \\
\mathrm{X}_{2.2} \\
\mathrm{X}_{2.3} \\
\mathrm{X}_{2.4}\end{array}$ & $\begin{array}{l}0,899 \\
0,895 \\
0,905 \\
0,931\end{array}$ & $\begin{array}{l}\text { Valid } \\
\text { Valid } \\
\text { Valid } \\
\text { Valid }\end{array}$ \\
\hline 3 & Kepuasan & $\begin{array}{l}\mathrm{Y}_{1.1} \\
\mathrm{Y}_{1.2} \\
\mathrm{Y}_{1.3} \\
\mathrm{Y}_{1.4}\end{array}$ & $\begin{array}{l}0,925 \\
0,906 \\
0,906 \\
0,933\end{array}$ & $\begin{array}{l}\text { Valid } \\
\text { Valid } \\
\text { Valid } \\
\text { Valid }\end{array}$ \\
\hline 4 & Loyalitas Pelanggan & $\begin{array}{l}\mathrm{Y}_{2.1} \\
\mathrm{Y}_{2.2} \\
\mathrm{Y}_{2.3} \\
\mathrm{Y}_{2.4} \\
\mathrm{Y}_{2.5}\end{array}$ & $\begin{array}{l}0,897 \\
0,869 \\
0,888 \\
0,928 \\
0,957\end{array}$ & $\begin{array}{l}\text { Valid } \\
\text { Valid } \\
\text { Valid } \\
\text { Valid } \\
\text { Valid }\end{array}$ \\
\hline
\end{tabular}

Sumber: Data diolah, 2018

Hasil olah data pada Tabel 1 menunjukkan bahwa nilai koefisien korelasi dari masing-masing indikator memiliki nilai lebih besar dari $0,3(\mathrm{r} \geq 0,30)$, hal ini menunjukkan bahwa semua instrumen penelitian yang digunakan adalah valid.

Reliabilitas menunjukkan tingkat konsistensi dan stabilitas data atau temuan. Pada penelitian ini uji reliabilitas menggunakan nilai cronbach's alpha dengan taraf $\alpha$ diatas 0,6 (cronbach's alpha 20,6 ). Hasil uji reliabilitas dari variabel-variabel yang diuji dapat dilihat pada Tabel 2. 
Tabel 2.

Hasil Uji Reliabilitas

\begin{tabular}{cclcc}
\hline No & $\begin{array}{c}\text { Jumlah } \\
\text { Item Pertanyaan }\end{array}$ & \multicolumn{1}{c}{ Variabel } & $\begin{array}{c}\text { Cronbach's } \\
\text { Alpa }\end{array}$ & keterangan \\
\hline 1 & 5 & Kualitas Pelayanan & 0,917 & Reliabel \\
& & Persepsi harga & 0,927 & Reliabel \\
2 & 4 & Kepuasan & 0,937 & Reliabel \\
3 & 4 & Loyalitas Pelanggan & 0,945 & Reliabel \\
\hline
\end{tabular}

Sumber: Data diolah, 2018

Tabel 2 menunjukkan bahwa seluruh variabel dalam penelitian ini telah memenuhi syarat reliabilitas. Hal ini ditunjukan dengan nilai cronbach's alpha untuk setiap variabel lebih besar dari 0,60.

Pengujian hipotesis dalam penelitian ini menggunakan teknik analisis jalur (path analysis), hasil analisis jalur dapat disajikan secara rici sebagai berikut:

Tabel 3.

Hasil Analisis Jalur Persamaan Regresi 1

\begin{tabular}{lccccc}
\hline \multicolumn{1}{c}{ Model } & \multicolumn{1}{c}{$\begin{array}{c}\text { Unstandardized Coefficients } \\
\text { B }\end{array}$} & $\begin{array}{c}\text { Standardized } \\
\text { Coefficients } \\
\text { Beta }\end{array}$ & T & Sig. \\
\hline 1 (Constant) & 4,171 & 0,997 & & 4,185 & 0,000 \\
$\begin{array}{l}\text { Kualitas } \\
\text { Pelayanan }\end{array}$ & 0,345 & 0,066 & 0,451 & 5,239 & 0,000 \\
$\begin{array}{l}\text { Persepsi Harga } \\
\quad \mathrm{R}_{1}^{2}: 0,554\end{array}$ & $\begin{array}{c}0,337 \\
\text { F Statistik: } 72,745\end{array}$ & $\begin{array}{c}0,081 \\
\text { Sig F: } 0,000\end{array}$ & & \\
\hline
\end{tabular}

Sumber: Data diolah, 2018

Persamaan struktural yang dihasilkan berdasarkan hasil analisis jalur struktural I pada Tabel 10 adalah sebagai berikut:

$$
\begin{aligned}
& Y_{1}=\beta_{1} X_{1}+\beta_{2} X_{2}+1 \ldots \ldots \ldots \ldots \ldots \ldots \ldots \ldots \ldots \ldots \ldots \ldots \ldots \ldots \ldots \ldots \ldots \ldots \ldots \ldots \ldots n \\
& Y_{1}=0,451 X_{1}+0,357 X_{2}+1
\end{aligned}
$$

Nilai $\beta_{1}$ adalah sebesar 0,451 memiliki arti bahwa kualitas pelayanan berpengaruh positif terhadap kepuasan, sehingga dapat diinterprestasikan jika 
faktor kualitas pelayanan meningkat maka kepuasan juga akan mengalami peningkatan.

Nilai $\beta_{2}$ adalah sebesar 0,357 memiliki arti bahwa persepsi harga berpengaruh positif terhadap kepuasan, sehingga dapat diinterprestasikan jika persepsi harga meningkat maka kepuasan pelanggan juga akan mengalami peningkatan.

\section{Tabel 4.}

Hasil Analisis Jalur Persamaan Regresi 2

\begin{tabular}{|c|c|c|c|c|c|}
\hline \multirow[t]{2}{*}{ Model } & \multicolumn{2}{|c|}{ Unstandardized Coefficients } & \multirow{2}{*}{$\begin{array}{c}\text { Standardized } \\
\text { Coefficients } \\
\text { Beta } \\
\end{array}$} & \multirow[t]{2}{*}{$\mathbf{T}$} & \multirow[t]{2}{*}{ Sig. } \\
\hline & B & Std. Error & & & \\
\hline 1 (Constant) & $-0,700$ & 1,182 & & $-0,592$ & 0,555 \\
\hline Kualitas & 0,288 & 0,081 & 0,269 & 3,566 & 0,001 \\
\hline \multicolumn{6}{|l|}{ Pelayanan } \\
\hline Persepsi Harga & 0,231 & 0,096 & 0,174 & 2,397 & 0,018 \\
\hline Kepuasan & 0,705 & 0,102 & 0,502 & 6,897 & 0,000 \\
\hline $\mathrm{R}_{1}^{2}: 0,726$ & \multicolumn{2}{|c|}{ F Statistik: 102,318} & Sig F: 0,000 & & \\
\hline
\end{tabular}

Sumber: Data diolah, 2018

$$
\begin{gathered}
Y_{2}=\beta_{3} X_{1}+\beta_{4} X_{2}+\beta_{5} Y_{1}+2 \ldots \ldots \ldots \ldots \\
Y_{2}=0,269 X_{1}+0,174 X_{2}+0,502 X_{3}+2
\end{gathered}
$$

Nilai $\beta_{3}$ adalah sebesar 0,269 , memiliki arti bahwa kualitas pelayanan berpengaruh positif terhadap loyalitas, sehingga dapat diinterprestasikan jika kualitas pelayanan meningkat maka loyalitas akan mengalami peningkatan.

Nilai $\beta_{4}$ adalah sebesar 0,174 , memiliki arti bahwa persepsi harga berpengaruh terhadap loyalitas, sehingga dapat diinterprestasikan jika persepsi harga meningkat maka loyalitas akan mengalami peningkatan.

Nilai $\beta_{5}$ adalah sebesar 0,502 , memiliki arti bahwa kepuasan berpengaruh positif terhadap loyalitas, sehingga dapat diinterprestasikan jika kepuasan meningkat maka loyalitas akan mengalami peningkatan. 
Uji asumsi klasik dilakukan dengan tujuan untuk memastikan hasil yang diperoleh memenuhi asumsi dasar di dalam analisis regresi. Hasil uji asumsi klasik yang dilakukan dalam penelitian ini adalah uji normalitas, uji multikolinearitas dan uji heteroskedastisitas. Hasil uji dari asumsi klasik yang diolah dengan bantuan software SPSS disajikan sebagai berikut:

Uji normalitas ini bertujuan untuk mengetahui apakah residual dari model regresi yang dibuat berdistribusi normal atau tidak. Uji Kolmogrov Smirnov diperlukan untuk menguji apakah data yang digunakan normal atau tidak. Apabila koefisien Asymp sig (2-tailed) lebih besar 0,05 maka data tersebut dikatakan berdistribusi normal. Hasil uji Kolmogrov Smirnov dapat disajikan pada Tabel 5.

Tabel 5.

Hasil Uji Normalitas Persamaan Regresi 1

\begin{tabular}{cc}
\hline & Unstandardized Residual \\
\hline N & 120 \\
Kolmogrov - Smirnov Z & 0,872 \\
Asymp. Sig. $(2-$ tailed $)$ & 0,433
\end{tabular}

Sumber: Data diolah, 2018

Tabel 5 menunjukkan bahwa nilai Kolmogrov - Smirnov $Z$ sebesar 0,872 sedangkan nilai Asymp. Sig. $(2$ - tailed) sebesar 0,433 lebih besar dari nilai alpha 0,05. Hasil tersebut mengindikasikan bahwa model persamaan regresi 1 berdistribusi normal.

Tabel 6.

Hasil Uji Normalitas Persamaan Regresi 2

\begin{tabular}{cc}
\hline & Unstandardized Residual \\
\hline N & 120 \\
Kolmogrov - Smirnov $Z$ & 0,691 \\
Asymp. Sig. $(2-$ tailed $)$ & 0,726 \\
\hline Sumber: Data diolah, 2018
\end{tabular}


Tabel 6 menunjukkan bahwa nilai Kolmogrov - Smirnov Z sebesar 0,691 sedangkan nilai Asymp. Sig. $(2$ - tailed $)$ sebesar 0,726 lebih besar dari nilai alpha 0,05. Hasil tersebut mengindikasikan bahwa model persamaan regresi 2 berdistribusi normal.

Uji multikolinieritas bertujuan untuk menguji apakah pada model regresi ditemukan adanya korelasi antara variabel bebas. Adanya multikolenieritas nilai tolerance atau varianceinflantion factor (VIF). Jika nilai tolerance lebih dari $10 \%$ atau VIF kurang dari 10, maka dikatakan tidak ada multikolinearitas.

Tabel 7.

Hasil Uji Multikolinearitas Persamaan Regresi 1

\begin{tabular}{lcc}
\hline \multicolumn{1}{c}{ Variabel } & Tolerance & VIF \\
\hline Kualitas Pelayanan & 0,515 & 1,942 \\
Persepsi Harga & 0,515 & 1,943 \\
\hline
\end{tabular}

Sumber: Data diolah, 2018

Hasil pada Tabel 7 menunjukkan nilai tolerance untuk variabel kualitas pelayanan dan persepsi harga lebih besar dari 10\% (0,010 dan nilai VIF lebih kecil dari 10. Maka dapat disimpulkan model persamaan regresi 1 bebas dari multikolinearitas.

Tabel 8.

Hasil Uji Multikolinearitas Persamaan Regresi 2

\begin{tabular}{lcc}
\hline \multicolumn{1}{c}{ Variabel } & Tolerance & VIF \\
\hline Kualitas Pelayanan & 0,471 & 2,399 \\
Persepsi Harga & 0,449 & 2,228 \\
Kepuasan & 0,446 & 2,244 \\
\hline
\end{tabular}

Sumber: Data diolah, 2018

Hasil pada Tabel 8 menunjukkan nilai tolerance untuk variabel kualitas pelayanan, persepsi harga dan kepuasan lebih besar dari 10\% (0,010 dan nilai VIF 
lebih kecil dari 10. Maka dapat disimpulkan model persamaan regresi 2 bebas dari multikolinearitas.

Uji heterokedastisitas bertujuan untuk mengetahui apakah dalam model regresi terjadi ketidaksamaan varians dan residual satu pengamatan ke pengamatan lain yang dilakukan dengan uji Glejser. Jika tidak ada satu pun variabel bebas yang berpengaruh signifikan terhadap nilai absolute residual atau nilai signifikansinya di atas 0,05 maka dapat disimpulkan model regresi tidak mengandung gejala heterosdekastisitas.

\section{Tabel 9.}

Hasil Uji Heteroskedatisitas Persamaan Regresi 1

\begin{tabular}{lccccc}
\hline \multicolumn{1}{c}{ Model } & $\begin{array}{c}\text { Unstandardied } \\
\text { Coefficients } \\
\text { Std. Error }\end{array}$ & $\begin{array}{c}\text { Standardized } \\
\text { Coefficients } \\
\text { Beta }\end{array}$ & T & Sig. \\
\hline 1 (Constant) & 2,362 & 0,615 & & 3,840 & 0,000 \\
$\begin{array}{l}\text { Kualitas } \\
\text { pelayanan }\end{array}$ & 0,13 & 0,041 & 0,051 & 0,406 & 0,685 \\
$\begin{array}{l}\text { Persepsi harga } \\
\text { Buber: } \text { Data diolah, } 2018\end{array}$ & $-0,85$ & 0,050 & -0.214 & $-1,692$ & 0,093 \\
\hline
\end{tabular}

Hasil Tabel 9 menunjukkan bahwa nilai signifikansi dari variabel kualitas pelayanan sebesar 0,685 dan persepsi harga sebesar 0,093 lebih besar dari 0,05. sehingga dapat disimpulkan tidak terdapat pengaruh antara variabel bebas terhadap absolute residual, dengan demikian model yang digunakan tidak mengandung gejala heteroskedastisitas. 
Tabel 10.

Hasil Uji Heteroskedatisitas Persamaan Regresi 2

\begin{tabular}{lccccc}
\hline \multicolumn{1}{c}{ Model } & \multicolumn{2}{c}{$\begin{array}{c}\text { Unstandardied } \\
\text { Coefficients } \\
\text { Std. Error }\end{array}$} & $\begin{array}{c}\text { Standardized } \\
\text { Coefficients } \\
\text { Beta }\end{array}$ & T & Sig. \\
\hline 1 (Constant) & 2,322 & 0,743 & & 3,127 & 0,002 \\
Kualitas & 0,088 & 0,051 & 0,245 & 1,742 & 0,084 \\
pelayanan & $-0,097$ & 0,060 & -0.218 & $-1,611$ & 0,110 \\
Persepsi harga & $-0,068$ & 0,064 & $-0,143$ & $-1,054$ & 0,294 \\
Kepuasan & & & & &
\end{tabular}

Hasil Tabel 10 menunjukkan bahwa nilai signifikansi dari variabel kualitas pelayanan sebesar 0,084, persepsi harga sebesar 0,110 dan kepuasan sebesar 0,294 lebih besar dari 0,05. sehingga dapat disimpulkan tidak terdapat pengaruh antara variabel bebas terhadap absolute residual, dengan demikian model yang digunakan tidak mengandung gejala heteroskedastisitas.

Hasil penelitian menunjukkan bahwa kualitas pelayanan $\left(\mathrm{X}_{1}\right)$ berpengaruh positif dan signifikan terhadap kepuasan $\left(\mathrm{Y}_{1}\right)$ dapat diterima dengan koefisien beta sebesar 0,451 dan tingkat signifikan sebesar 0,000 ( $\mathrm{p} \leq 0,05)$. Hasil tersebut menyatakan bahwa kualitas pelayanan berpengaruh positif dan signifikan terhadap kepuasan. Artinya bahwa, semakin baik kualitas pelayanan yang diberikan Gojek maka akan dapat meningkatkan kepuasan pada pelanggan.

Berdasarkan hasil wawancara, kualitas pelayanan yang ditampilkan Gojek seperti kerapihan, kebersihan, kecepatan dan kemudahan menggunakan aplikasi Gojek sudah dirasa baik dan dapat memenuhi harapan dari pelanggan sehingga ratarata pelanggan Gojek sudah merasa puas dengan kualitas pelayanan yang diberikan Gojek.

Hasil penelitian ini sejalan dengan penelitian yang dilakukan Khairani dan Hati (2017) menyatakan bahwa kualitas pelayanan berpengaruh positif dan 
signifikan terhadap kepuasan pelanggan online transportation. Hasil penelitian ini juga sejalan dengan penelitian yang dilakukan oleh Montolalu (2013)yang dilakukan pada industri hotel yang menunjukkan bahwa kualitas pelayanan berpengaruh positif dan signifikan terhadap kepuasan pelanggan.

Hasil penelitian menunjukkan bahwa variabel persepsi harga $\left(\mathrm{X}_{2}\right)$ berpengaruh positif dan signifikan terhadap kepuasan $\left(\mathrm{Y}_{1}\right)$ dapat diterima dengan koefisien beta sebesar 0,357 dan tingkat signifikan $0,000(\mathrm{p} \leq 0,05)$. Hasil tersebut menyatakan persepsi harga berpengaruh positif dan signifikan terhadap kepuasan. Artinya semakin baik persepsi pelanggan terhadap tarif Gojek maka pelanggan Gojek merasa semakin puas.

Persepsi harga seringkali dihubungkan dengan manfaat yang dirasakan atas suatu barang atau jasa, jika manfaat yang dirasakan meningkat maka persepsi pelanggan akan menjadi baik dan menciptakan kepuasan pelanggan yang maksimal (Tjiptono, 2014). Jadi dapat disimpulkan persepsi yang positif merupakan hasil dari rasa puas akan suatu pembelian yang dilakukan, sedangkan persepsi yang negatif merupakan hasil dari ketidakpuasan atas produk atau jasa yang dibeli.

Hal ini sejalan dengan penelitian yang dilakukan oleh Hermawan et al. (2017) yang menyatakan persepsi harga berpengaruh positif dan signifikan terhadap kepuasan pelanggan pada penyedia jasa telekomunikasi. Penelitian lain juga dilakukan oleh Harjati dan Venesia (2015) dimana penelitian dilakukan pada indutri penerbangan yang menyatakan bahwa persepsi harga berpengaruh positif dan signifikan terhadap kepuasan pelanggan. 
Hasil penelitian menunjukkan bahwa variabel kualitas pelayanan $\left(\mathrm{X}_{1}\right)$ berpengaruh positif dan signifikan terhadap loyalitas pelanggan $\left(\mathrm{Y}_{2}\right)$ dapat diterima dengan koefisien beta sebesar 0,269 dan tingkat signifikan 0,001 ( $\mathrm{p} \leq 0,005)$. Hasil tersebut menyatakan kualitas pelayanan berpengaruh positif dan signifikan terhadap loyalitas pelanggan. Artinya semakin kualitas pelayanan Gojek ditingkatkan maka loyalitas pelanggan akan meningkat.

Hal ini ada hubungannya dengan kebijakan standarisari pelayanan yang ditentukan oleh perusahaan (Gojek) untuk para pengemudi Gojek dari waktu ke waktu semakin menunjukkan kualitas yang baik dan kerjasama yang baik antara perusahaan dengan mitra Gojek. Seperti misalnya pemberian bonus ketika pengemudi Gojek dapat mencapai point yang ditentukan, pemberian bonus juga ditentukan dari kinerja pengemudi Gojek yang dinilai melalui review yang diberikan oleh pelanggan setelah menggunakan layanan Gojek. Kebijakan ini tentu akan mengharuskan para pengemudi Gojek untuk selalu berusaha memberikan pelayanan yang terbaik kepada penggunanya. Namun pada kenyataannya masih ada beberapa pengemudi Gojek yang belum memberikan pelayanan sesuai dengan standarisasi yang ditentukan perusahaan. Masyarakat pada umumnya menilai kualitas pelayanan Gojek secara keseluruhan dan bukan secara individual dari sisi pengemudi Gojek saja. Inilah yang menyebakan pelanggan tetap loyal dengan Gojek karena merasa puas dengan kualitas pelayanan yang telah diberikan.

Hal ini diperkuat oleh penelitian yang dilakukan Wendha dkk. (2013) yang menyatakan bahwa kualitas pelayanan berpengaruh positif dan signifikan terhadap loyalitas pelanggan maskapai garuda indonesia. Hal serupa diungkapkan oleh 
Farida dkk. (2016) yang mengungkapkan kualitas pelayanan berpengaruh positif dan signifikan terhadap loyalitas pelanggan jasa transportasi taksi Kota Semarang.

Hasil penelitian menunjukkan bahwa variabel persepsi harga $\left(\mathrm{X}_{2}\right)$ berpengaruh positif dan signifikan terhadap loyalitas pelanggan $\left(\mathrm{Y}_{2}\right)$ dapat diterima dengan koefisien beta sebesar 0,174 dan tingkat signifikan sebessar 0,018 ( $\mathrm{p} \leq$ 0,05). Hasil tersebut menyatakan persepsi harga berpengaruh positif dan signifikan terhadap loyalitas pelanggan. Artinya semakin tarif Gojek dipersepsikan lebih murah dibandingkan perusahaan lain maka loyalitas pelanggan Gojek semakin meningkat.

Hal ini ada hubungannya dengan semenjak awal kemunculannya, Gojek sebagai layanan jasa transportasi berbasis online bila dilihat dari sisi harga, tarif yang ditentukan tidak banyak mengalami perubahan. Justru dari faktor eksternal perusahaan seperti jasa transportasi konvensional yang mengintervensi agar Gojek memberikan harga yang lebih competitif. Rata - rata pelanggan mempersepsikan tarif Gojek sudah sesuai dengan manfaat yang diharapkan ketika menggunakannya. Hal ini dapat diartikan bahwa pelanggan merasa puas atas tarif yang diberikan Gojek dibandingkan perusahaan lain. Untuk itulah sampai saat ini, para pelanggan Gojek masih tetap loyal dan setia menggunakan Gojek.

Hal ini didukung deengan penelitian yang dilakukan oleh Hermawan et al. (2017) yang menyatakan persepsi harga berpengaruh positif dan signifikan terhadap loyalitas pelanggan penyedia jasa telekomunikasi. Penelitian yang dilakukan Mahmud et al. (2013) pada industri jasa penerbangan komersial juga menyatakan harga berpengaruh positif dan signifikan terhadap loyalitas pelangggan. 
Hasil penelitian menujukkan bahwa variabel kepuasan $\left(\mathrm{Y}_{1}\right)$ berpengaruh positif dan signifikan terhadap loyalitas pelanggan $\left(\mathrm{Y}_{2}\right)$ dapat diterima dengan koefisien beta sebesar 0,502 dan tingkat signifikan sebesar 0,000 ( $\mathrm{p} \leq 0,05)$. Hasil tersebut menyatakan kepuasan berpengaruh positif dan signifikan terhadap loyalitas pelanggan. Artinya semakin tinggi kepuasan pelanggan Gojek maka loyalitas pelanggan semakin meningkat.

Gojek sangat peduli dengan kepuasan pelanggan baik dari segi kualitas produk, kualitas pelayanan, harga, dan promosi. Hal tersebut dapat dilihat dari inovasi yang selalu dilakukan oleh Gojek agar dapat memenuhi seluruh kebutuhan pelanggannya seperti penambahan beberapa jenis layanan jasa pada aplikasi Gojek. Pelanggan juga dapat memberikan feedback atas pelayanan yang diberikan sehingga Gojek dapat mengetahui tanggapan pelanggan setelah menggunakan jasa Gojek. Potongan harga yang diberikan kepada pelanggan yang melakukan pembayaran via Go-Pay juga membuat pelanggan merasa puas sehingga pelanggan menjadi loyal kepada Gojek.

Hal ini didukung oleh penelitian yang dilakukan oleh Basir et al. (2015) yang menyatakan kepuasan berpengaruh positif dan signifikan terhadap loyalitas pelanggan jasa transportasi. Penelitian yang dilakukan Jonathan (2013) pada perusahaan travel juga menyatakan bahwa kepuasan berpengaruh positif dan signifikan terhadap loyalitas pelanggan.

Secara teoritis, Penelitian ini berimplikasi terhadap pengembangan konsep yang berkaitan dengan kualitas pelayanan, persepsi harga, kepuasan, dan loyalitas pelanggan Gojek Kota Denpasar. Penelitian ini memperkaya bukti empiris 
hubungan kualitas pelayanan dan persepsi harga terhadap kepuasan dan loyalitas pelanggan. Hasil penelitian ini mendukung hasil studi bahwa semakin baik kualitas pelayanan yang diberikan Gojek, maka pelanggan akan merasa puas sehingga menjadi loyal kepada Gojek.

Secara praktis penelitian ini memberi beberapa implikasi. Kualitas pelayanan mampu menigkatkan kepuasan dan loyalitas pelanggan Gojek. Pihak manajemen Gojek harus selalu memperhatikan kualitas pelayanan yang diberikan seperti kebersihan, kerapihan, kecepatan dan cara pemesanan sehingga kepuasan pelanggan tetap terjaga. Persepsi harga mampu meningkatkan kepuasan pelanggan Gojek di Kota Denpasar. Hal ini menunjukkan tarif harga yang diberikan Gojek sudah dipersepsikan baik oleh pelanggan, tetapi pihak manajemen Gojek perlu lebih memperhatikan tarif yang diberikan agar lebih kompetitif dengan pesaing dan sesuai dengan kemampuan pelanggan.

Secara keseluruhan pelanggan sudah merasa puas dengan kualitas pelayanan dan tarif yang diberikan Gojek. Namun ada beberapa indikator yang masih perlu diperhatikan seperti kecepatan pengemudi Gojek dalam memberikan pelayanan dan perbandingan harga dengan pesaing. Dilihat dari sisi loyalitas, pelanggan memiliki loyalitas yang tinggi kepada Gojek, ini mengindikasikan bahwa pelanggan memiliki niat untuk menggunakan Gojek secara terus menerus dan mereferensikan kepada orang lain. Maka pihak manajemen diharapkan mampu selalu memberikan pelayanan yang optimal sehingga kepuasan dan loyalitas pelanggan Gojek tetap terjaga. 


\section{SIMPULAN DAN SARAN}

Berdasarkan pembahasan hasil penelitian yang telah dilakukan, maka dapat disimpulkan bahwa:(1) Kualitas pelayanan berpengaruh positif dan signifikan terhadap kepuasan. Hal ini berarti semakin baik kualitas pelayanan yang diberikan Gojek, maka tingkat kepuasan pelanggan Gojek di Kota Denpasar akan meningkat,

(2) Persepsi harga berpengaruh positif dan signifikan terhadap kepuasan. Hal ini berarti apabila Gojek mampu memberikan tarif yang sesuai dengan harapan pelanggan maka pelanggan akan memiliki persepsi positif terhadap tarif Gojek. (3) Kualitas pelayanan berpengaruh positif dan signifikan terhadap loyalitas pelanggan. Hal ini berarti jika Gojek mampu memberikan kualitas pelayanan yang optimal maka pelanggan akan semakin loyal dengan Gojek, (4) Persepsi harga berpengauh positif dan signifikan terhadap loyalitas pelanggan. Ini berarti bahwa semakin pelanggan memiliki persepsi yang positif terhadap tarif Gojek maka pelanggan akan semakin loyal dengan Gojek, (5) Kepuasan berpengaruh positif dan signifikan terhadap loyalitas pelanggan. Hal ini berarti semakin tinggi tingkat kepuasan pelanggan Gojek di Kota Denpasar maka semakin tinggi pula tinggat loyalitas pelanggan Gojek.

Saran yang dapat diberikan dari penelitian ini antara lain: (1) Penelitian selanjutnya diharapkan dapat menyebarkan kuesioner ke wilayah yang lebih luas dan menambah variabel bebas yang mempunyai pengaruh terhadap kepuasan dan loyalitas pelanggan seperti kualitas produk, citra merek dan promosi. (2) Manajemen Gojek disarankan untuk lebih memperhatikan faktor-faktor yang mempengaruhi kepuasan dan loyalitas pelanggan, terutama dari segi kualitas 
pelayanan yang diberikan. Hal ini berdasarkan hasil penelitian, bahwa kualitas pelayanan paling signifikan berpengaruh terhadap kepuasan dan loyalitas pelanggan dibandingkan variabel persepsi harga.

\section{REFERENSI}

Ahmed, I., Nawaz, M. Usman, A. Shaukat, M. Ahmed, N. dan Rehman, W.2010. A Mediation of Customer Satisfaction Relationship Between Service Quality and Repurchase Intentions for The Telecom Sector in Pakistan: A Case Study of University Students. Journals of Business management, 4 (16): 3457-3462.

Akbar, M., dan Parves. N. 2009. Impact of Service Quality, Trust, and Customer Statisfaction on Customer Loyalty. ABAC Journal,29 (1):24-38.

Aryani, D., dan Rosinta, F .2010. Pengaruh Kualitas Layanan terhadap Kepuasan Pelanggan dalam Membentuk Loyalitas Pelanggan. JurnalIlmu Administrasi Dan Organisasi, 17 (2):114-126

Badan Pusat Statistik. 2017. Laju Pertumbuhan Penduduk Indonesia Tahun 2016. www.bps.go.id. (Diakses 13 november 2017).

Basir, M., Moding, B. Kamase, J. dan Hasan, S.2015. Effect of Service Quality, Orientation Services and Pricing on Loyalty and Customer Satisfaction in Marine Transportation Services. Journal of Humanities and Social Science Invention, 4 (6):01-06.

Boohene, R., dan Agyapong, G. 2011. Analysis of the Antecedents of Customer Loyalty of Telecommunication Industry in Ghana: The Case of Vodafone (Ghana). International Business Research,4 (1):229-240.

Dominic, G., dan Guzzo, R. 2010. Customer Satisfaction in the Hotel Industry: A Case Study from Sicily. International Journal of Marketing Studies, 2 (2):211

Farida, I., Tarmizi, A., dan November, Y. 2016. Analisis Pengaruh Bauran Pemasaran 7P Terhadap Kepuasan Pelanggan Gojek Online. Jurnal Riset Manajemen dan Bisnis. 1 (1): 31-40.

Ghozali, Imam. 2011. Partial least squares konsep, Metode dan Aplikasi Menggunakan Porgram Warp PLS 4.0. Semarang.

Gummusoy, A., dan Koseoglu, B. 2016. The Effects of Service Quality, Perceived Value and Price Fairness on Hotel Customers' Satisfaction and Loyalty. Journal of Economics Business and Management. 4 (9):523-527. 
Hasanah, U., dan Harti. 2012. Pengaruh Keragaman Menu, Harga Dan Kualitas Pelayanan Terhadap Loyalitas Pelanggan Dengan Kepuasan Sebagai Variabel Intervening Pada Waroeng "SS" (Spesial Sambel) Surabaya. Jurnal Pendidikan Tata Niaga. 01 (01): 9-15.

Harjati, L., dan Venesia, Y. 2015. Pengaruh Kualitas Layanan dan Prsepsi Harga Terhadap Kepuasan Pelanggan Pada Maskapai Penerbangan Tiger Air Mandala. E-Journal WIDYA Ekonomika. 1 (1) :64-74

Hermawan, B., Basalamah, S. Djamereng, A. dan Plyriadi, A.2017. Effect of Service Quality and Price Perception on Corporate Image, Customer Satisfaction and Customer Loyalty among Mobile Telecommunication Services Provider. Journal of Management and Social Sciences, 8 (1): 62-73.

Irawan, Handi. 2002. Kepuasan Pelanggan. Jakarta: PT Elex Media Komputindo.

Jonathan, H. 2013. Analisis Pengaruh E-service Quality Terhadap Customer Satisfaction yang Berdampak pada Customer Loyalty Pt Bayu Buana Travel tbk. Journal the Winner. 14 (2): 104-112.

Khairani dan Hati. 2013. The Effects of Perceived Service Quality towards Customer Satisfaction and Behavioral Intentions in Online Transportation. International Journal of Humanities and Management Sciences, 5 (1):23402344.

Kitapci, O., Akdogan, C., dan Dortyol, I. 2014. The Impact of Service Quality Dimensions on Patient Satisfaction, Repurchase Intentions and Word-ofMouth Communication in the Public Healthcare Industry. Journal of Social and Behavioral Sciences, 1 (14): 161-169.

Kurniasari dan Ernawati, N. 2012. Pengaruh Kepuasan Pelanggan, Kepercayaan, dan harga terhadap Loyalitas Pelanggan Laundry Kencling Semarang. Jurnal Mahasiswa Q MAN, 1 (3): 57-68.

Kurniasih, I. 2012. Pengaruh Harga dan Kualitas Pelayanan Terhadap Loyalitas Pelanggan Melalui Variable Kepuasan (Studi Pada Bengkel AHASS 0002Astra Motor Siliwangi Semarang). Jurnal Administrasi Bisnis. 1 (1): 37-40.

Lesander, C. 2013. Citra Merek, Kualitas Produk dan Promosi pengaruhnya TerhadapKepuasan Konsumen Pada Makanan Tradisional (Survey Pada Industri Rumah Tangga Dodol Daging Pala Audia di Tahuna Kab. Sangihe). Jurnal Emba, 1 (3): 284-293.

Lenzun, J., Massie, J., danAdare., D. 2014. Pengaruh Kualitas Produk, Harga, dan Promosi Terhadap Kepuasan Pelanggan Kartu Prabayar Telkomsel. Jurnal Emba. Vol.2 No.3, Hal.1237-1245.

Lupiyoadi, Rambat. 2013. Manajemen Pemasaran Jasa. Jakarta: Salemba Empat. 
Mahmud, A., Jussof, K., dan Hadijah, St. 2013.The Effect of Service Quality and Price on Satisfaction and Loyalty of Customer of Commercial Flight Service Industry. World Applied Sciences Journal, 3 (23): 354-359.

Montolalu, M. 2013. The Impact of Service Quality and Price to Customer Statisfaction and Customers Loyalty in Swiss-bellhotel Maleosan Manado. Jurnal EMBA, 1 (4):1491-1497.

Rahman, A., Kalam, A., dan Rahman, M. 2012. The Influence of Service Quality and Price on Customer Satisfaction: An Empirical Study on Restaurant Services in Khulna Division. Journal of Finance and Accounting, 3 (4):8-16

Rizan, M., Yulianti, D. dan Rahmi. 2015. The Influence of Price and Service Quality Of Brand Image And Its Impact on Customer Satisfaction Gojek (Students Study On A State University Of Jakarta). Jurnal Riset Manajemen Sains Indonesia (JRMSI),6 (2): 639-658.

Santoso, A., dan Aprianingsih, A. 2017. The Influence of Perceived Service and EService Quality to Repurchase Intention the Mediating Role of Customer Satisfaction Case Study: Go-Ride in Java. Journal of Business and Manajement, 6 (2):32-43.

Semuel, Hatane., Wijaya, dan Nadya. 2009. Service Quality, Perceive Value, Satisfaction, Trust, Dan Loyalty Pada PT. Kereta Api Indonesia Menurut Penilaian Pelanggan Surabaya. Jurnal ManajemenPemasaran, 4 (1):23-37.

Setiawan, H., dan Sayuti, A. 2017. Effects of Service Quality, Customer Trust and Corporate Image on Customer Satisfaction and Loyalty: An Assessment of Travel Agencies Customer in South Sumatra Indonesia. Journal of Bussiness and Management, 19 (3): 31-40.

Stanton, W. 2007. Prinsip-Prinsip Pemasaran. Jakarta: Erlangga.

Suwandi., Sularso, A., dan Suroso, I. 2015. Pengaruh Kualitas Layanan, Harga Dan Citra Merek TerhadapKepuasan Dan Loyalitas Pelanggan Pos Ekspres Di Kantor Pos Bondowoso an Situbondo. JEAM, 14 (2): 68-88

Tjiptono, Fandy. 2008. Pemasaran Strategik. Yogyakarta: Andi Offset.

Tjiptono, Fandy. 2012.Service Management Mewujudkan Layanan prima. Edisi 2. Yogyakarta: ANDI

Tjiptono, Fandy. 2014. Pemasaran Jasa. Malang: Bayumedia.

Wendha, P.A.A., Rahyuda, K. dan Suarsana, I. Gst. A. 2013. Pengaruh Kualitas Layanan Terhadap Kepuasan dan Loyalitas Pelanggan Garuda Indonesia Di Denpasar. Jurnal manajemen, strategi bisnis, dan kewirausahaan, 7 (1): 2426. 
E-Jurnal Manajemen Unud, Vol. 7, No. 11, 2018: 6041 - 6069

Yesenia dan Siregar, E. 2014. Pengaruh Kualitas Layanan dan Produk terhadap Kepuasan serta Loyalitas Pelanggan Kentuky Fried Chiken di Tangerang Selatan. Jurnal Ekonomi Manajemen Bisnis dan Akutansi (Emba), 2 (1): 9098

Zeithaml, Valarie, A dan Bitner, Mary, J. 2003. Service Marketing Integrating Customer Focus Across the Firm, 3rd edition. New York.Mc Graw Hill Inc. 